\title{
MEMBANGUN KEBAHAGIAAN GEOGRAFIK
}

\author{
Momon Sudarma \\ MAN 2, Kota Bandung \\ momonsudarma@yahoo.com; \\ http:/ / momonsudarma.blogdetik.com
}

\begin{abstract}
If there are people who feel comfortable, stay in one place, then that is characteristic of people who have geographic happiness. Unfortunately, the natural character and management ofeveryone's life, not always able to deliver himselfgeographichappiness. Existing conditions is the emergence of people's lifestyles are not comfortable, or restless living in the area.
\end{abstract}

Keywords: Geographic happiness, geography education.

\section{PENDAHULUAN}

\section{Latar Belakang}

Geografi adalah penjelasan mengenai permukaan bumi (Stewart, 1984/1999), atau secara lebih luas dikatakan bahwa geografi adalah ilmu yang mempelajari mengenai penduduk, tempat dan lingkungannya (people, place and environments) dari perspektif keruangan (NGS, 1994).

Setiap pembahasan materi apapun, senantiasa dijelaskan dengan menggunakan perspektif kelingkungan, kewilayan, dan kompleks keruangan. Perspektif-perspektif dimaksud, diposisikan sebagai objek formal yang menjadi pembeda antara disiplin ilmi geografi dengan kajian ilmu kebumian yang lainnya. Penjelasan mengenai fenomena geosfera senantiasa menyertakan mengenai konteks keruangannya.

Sebutan geografi sebagai mother of all science (Spellman, 2010), pada dasarnya bisa dimaknai bahwa perspektif geografi merupakan keterampilan hidup yang dibutuhkan oleh semua orang, termasuk orang nongeografi. Pada sisi lain, sebutan itu mengandung makna bahwa perspektif geografi dapat digunakan untuk alat-kaji mengenai berbagai fenomena geosfera. Termasuk mengenai tujuan dari hidup manusia itu sendiri.

Sebagaimana sering dikemukakan, bahwa tujuan hidup itu berharap mendapatkan kebahagiaan atau setidaknya kesenangan. Kebutuhan ini, seolah telah menjadi kebutuhan umum, kebutuhan bersama dan harapan dari semua pihak. Sayangnya, kajian mengenai masalah ini, lebih banyak diperhatikan oleh kalangan psikologi, pendidikan, atau teologi. Sementara kalangan geografi, kurang memberikan perhatian yang seksama terhadap masalah sepenting ini. 
Berbagai sumber yang ada di sekitar kita, kajian-kajian mengenai kebahagiaan, lebih ditekankan pada aspek psikologi atau teologis (agama). Padahal, secara filosofi sendiri, manusia itu bukan sekedar makhluk psikologis, tetapijuga makhlukbiologis, dan makhlukgeografis (homogeographicus). Artinya, persepsi manusia, kebutuhan hidup manusia, perilaku manusia, termasuk di dalamnya adalah kebahagiaan manusia tidak bisa dilepaskan dari konteks keruangannya, atau tempat dan lingkungannya. Oleh karena itu, melakukan kajian kebahagiaan pun, tidak bisa dilepaskan dari konteks keruangan atau konteks kegeografiannya.

Menggunakan perspektif seperti ini, dapat disederhanakan, bahwa pemenuhan kebutuhan manusia, tidak cukup sekedar dengan memberikan pemenuhan aspek psikologis, atau spiritualitas semata. Karena sesungguhnya, manusia bukanlah makhluk yang hidup di ruang hampa. Manusia adalah makhluk yang menempati ruang. Maka, kebahagiaan yang dijadikan tujuan dan kebutuhan hidupnya pun, sejatinya perlu dikontekskan dalam kaitannya dengan keruangan.

Pada sisi lain, kita menemukan sejumlah fakta unik dalam kehidupan ini. Ada sekelompok orang yang mampu menunjukkan sikap kebersikukuhannya untuk tinggal di satu tempat, yang menurut persepsi orang merupakan daerah rawan bencana. Ada orang yang berusaha keras untuk mempertahankan wilayahnya. Ada kelompok masyarakat, yang begitu kuat mencintai tanah airnya. Daripada melepaskan daerah tempat tinggalnya, malah dia sanggup untuk mengorbankan jiwa raganya.

Fenomena manusia yang rela berkorban dalam mempertahan tempat tinggal, rela tinggal di kampong halaman sendiri, walaupun banyak ancaman bencana, menunjukkan ada gejala psikologis yang terkait dengan persepsi ruangnya sendiri. Dalam konteks inilah, dengan menggunakan perspektif geografi manusia (human geography), kajian ini berusaha untuk menjelaskan mengenai kebahagiaan dalam konteks geografi.

\section{Tujuan Penulisan}

Kajian ini disandarkan pada perspektif tujuan pendidikan geografi. Asumsi-asumsi yang dikembangkan, yaitu mengenai tujuan dari pembelajaran geografi. Wacana ini, jelas-jelas menganut pemikiran bahwa tujuan pendidikan geografi tidak sekedar memberikan pengetahuan-pengetahuan geografi. Tujuan pendidikan geografi bukan untuk menjadikan manusia sebagai kamusdata informasi geografi. Tujuan pendidikan geografi adalah menjadi alat bagi manusia untuk mewujudkan kebutuhan hidup manusia. Dengan kata lain, andai yang menjadi kebutuhan manusia itu adalah sebuah kebahagiaan, maka tujuan pendidikan geografi pun adalah menghantarkan manusia untuk bisa hidup bahagia di ruangnya masing-masing.

Secara spesifik, tujuan dari kajian ini adalah (a) untuk menjelaskan mengenai fakta kebahagiaan geografik, (b) variasi tujuan dari pendidikan 
geografi, dan(c) implikasi dari kebahagiaan geografi terhadap kehidupan praktis manusia. Dengan rincian kajian dimaksud, diharapkan mampu memberikan gambaran umum mengenai tujuan umum pendidikan geografi.

\section{METODE}

Kajian ini lebih merupakan bentuk kajian kepustakaan, yang dipadukan dengan pendekatan reflektif yang dikembangkan Anthony Giddens (1999). Maksud dari pendekatan reflektif itu, yang menggunakan konfrontasi rasional antara fenomena empiris, apresiasi subjek (manusia) dengan kerangka teoritik yang berkembang dalam ilmu sosial. Dengan pendekatan inilah, maka fakta manusia yang butuh rasa bahagia, tidak sekedar dikaitkan dengan konteks psikologis, tetapi juga dilihat dalam kaitannya dengan konteks keruangannya. Relasi dan interpretasi antar aspek keilmuan (data, persepsi, dan teori) itu secara dinamis digunakan untuk menemukan pemahaman yang lebih bisa dipertanggungjawabkan secara keilmuan.

\section{HASIL DAN PEMBAHASAN}

Pada bagian ini, akan dikemukakan paparan dalam beberapa subbahasan, yaitu ilustrasi fenomena, seting lingkungan, fokus kajian, tahapan kesadaran geografik, dan beberapa implikasi dan kasus geografi manusia yang relevan dengan penguatan kebahagiaan geografik.

\section{Ilustrasi Fenomena}

Ahmadun. Itulah nama seorang petani yang tinggal pada sebuah rumah, yang ada di kawasan pesawahan. Lokasinya ada di salah satu desa di Majalengka. Dia sudah lama tinggal di tempat ini. Bahkan, penduduk desa ini menganggapnya bahwa dialah satu-satunya keluarga yang bertahan tinggal di tengah kawasan pesawahan, dan beranak cucu di tempat itu. Kawasan pesawahan itu, bukan miliknya. Ada sebagian petak yang menjadi miliknya, tetapi bagian terluas lainnya adalah milik warga desa yang tinggal di pusat Pedesaan. Sementara sawah yang digarapnya itu, berada di pinggir desa dan jarak rumah Ahmadun ke kampung-Desa itu sekitar $1 \mathrm{~km}$. Dengan keteguhan Ahmadun itulah, malah kemudian hari banyak orang yang ikut mendirikan rumah di tengah pesawahan yang relatif jauh ke pusat pemerintahan desa tersebut.

Setiap lebaran, termasuk penulis, kerap berkunjung ke keluarga Ahmadun untuk bershilaturahmi. Di rumahnya itu, terdapat banyak hasil pertanian, dan juga peternakan. Peralatan modern pun, tak ketinggalan. Seperti motor, televisi atau kulkas kini sudah hadir di rumah Ahmadun.

Bangunan rumah berdiri di atas lahan berukuran $12 \times 14 \mathrm{~m}$, dibuat secara semi permanen. Berdiri kokoh menghadap ke sebelah utara, kemudian 
halaman depan rumah yang luas, cukup untuk 4 buah kendaraan. Maklum ada di daerah pedesaan, area kosong masih sangat luas. Bagian depan rumah, berbatasan langsung dengan sungai, kemudian di belakang rumahnya sekitar 15 meter, sudah dihadapkan pada daerah terbih. Topografi di belakang rumah memang agak sedikit terjal.

Ahmadun yang kini berusia sekitar 65 tahun, 'menyulap' (merekayasa) daerah tebing itu sebagai bagian arsitektur bangunan rumahnya. Tebing baginya adalah arsitektur alam yang bisa dimaksimalkan sebagai bagian dari nilai estetika rumahnya sendiri. Sehingga pada akhirnya, kendati ada di pinggiran tebing, rumah itu tampak modern, indah dan bernuansa teknologi 'canggih', karena mampu memanfaatkan topografi alam sebagai bagian dari struktur rumah huninya.

Sudah cukup lama. Setidaknya hampir 20 tahun dia tinggal di rumah tersebut. Ahmadun hidup di kawasan tersebut dengan penuh suka cita, membangun keluarga dan memanfaat lingkungan alamnya. Kenyataan ini, menjadi satu daya tarik tersendiri, baik bagi masyarakat yang pernah berkunjung ke tempatnya, atau siapapun yang mengkaji masalah kehidupan kawasan. Fakta itu merupakan tema menarik untuk dikaji dan dicermati secara seksama dalam konteks kehidupan manusia.

\section{Fokus Kajian}

Bila dicermati dengan seksama, kasus seperti Ahmadun ini merupakan contoh ril dari adanya kenyamanan diri tinggal di suatu tempat. Dia bangga dengan tempat tinggalnya. Dia bahagia tinggal di rumahnya sendiri. Ahmadun tidak memiliki impian untuk pindah tempat, atau menyesali tempat tinggalnya. Ahmadun memiliki rasa bahagia, dan suka cita menempati lokasi yang kini menjadi tempat huninya. Pada konteks itulah, sikap yang ditunjukkan Ahmadun sebagai bentuk nyata dari kebahagiaan geografik (geographic happiness).

Seolah memaksakan, itulah yang diungkapkan oleh kelompok yang skeptik pada ide pentingnya membangun kebahagiaan geografik. Mereka memberikan sandaran bahwa ide-ide seperti ini, diposisikan sebagai ide latah, dan sekedar memperpanjang wacana belaka. Tidak memiliki nilai praksisnya bagi kehidupan manusia. Pembincangan mengenai kebahagiaan, bukanlah aspek geografik, tetapi lebih merupakan aspek psikologis belaka. Oleh karena itu, tidak ada relevansinya dengan kebutuhan kalangan geografi untuk membincangkan masalah-masalah seperti ini.

Kalangan akademisi pun, luput dari ikhtiar untuk mewacanakan hal ini. Sampai tulisanini dituangkan, penulis belum menemukan satu tulisan berbahasa Indonesia yang berusaha mengulas masalah kebahagiaan geografik. Dengan menggunakan alat pelacak "search" di internet, penulis tidak menemukan artikel atau tulisan yang memuat mengenai kebahagiaan geografik. Data ini, merupakan informasi awal bahwa kenyataan itu kenyataan bisa jadi merupakan wujud nyata bahwa persoalan usaha membangun kebahagiaan geografik, 
belum merupakan satu kebutuhan mendesak, baik bagi kalangan akademisi (khususnya ilmuwan geografik, ekologi) maupun masyarakat Indonesia pada umumnya.

Sementara bila kita melihat fakta yang ada - disadari atau tidak, mau atau tidak mau - nalar kita akan tertuntun pada pentingnya usaha untuk menata lingkungan, sehingga menjadi tempat yang nyaman dihuni, ditinggali dan atau dijadikan tempat untuk bereskpresi. Informasi ini, merupakan hal yang penting, dan akan menjadi sebuah kebutuhan mendesak bagi kita semua.

Dalam membahas masalah ini, ada dua pokok bahasan penting yang bisa mengantarkan kita pada ujung pembahasan. Pertama, pembahasan mengenai setting sosial atau karakter lingkungan. Kedua, kajian mengenai tahapan kecerdasan geografik. Melalui dua paparan ini, diharapkan akan menjadi sebuah gambaran umum, mengenai apa yang dimaksud dengan kebahagiaan geografik.

Dalam Seminar dan Lokakarya Peningkatan Kualitas Pengajaran Geografi di IKIP Semarang tahun 1989, disepakati bahwa geografi memiliki misi untuk membekali peserta didiknya dalam (a) pengetahuan kebumian, (b) keterampilan hidup, (c) kesadaran mental, (d) kepuasaan personal, serta (e) kesadaran sebagai warga negara.

Misi membantu dan mewujudkan kepuasan personal itu, pada dasarnya hanya menjadi modal untuk menjadi kepuasaan sosial, kemudian kepuasan ruang, yang selanjutnya kita sebut sebagai kebahagiaan geografik. Hal itu, terjadi karena kebahagiaan geografi tidak dapat diwujudkan bila tidak ada kepuasan personal, tetapi kepuasan personal bukan tujuan akhir dari kehidupan di dunia ini. Karena manusia hidup tidak sendirian, dan tidak bisa melepaskan diri dari ikatan kehidupan dengan unsur kehidupan yang lainnya, seperti faktor lingkungan dan sosial budaya yang ada di sekitarnya.

Dalam konteks itu, wacana ini, berusaha untuk mengurai lebih lanjut mengenai kebutuhan manusia untuk membangun kebahagiaan geograpi. Dengan cermatan seperti ini, diharapkan dapat membantu untuk menjelaskan fenomena ke'keukeuhan' (bersiteguhnya) manusia dalam mempertahankan lingkungan tempat tinggalnya.

\section{Seting Lingkungan}

Indonesia adalah sebuah negara yang luas. Dari ujung Sabang di Sumatera sampai Merauke yang ada di Papua. Kawasan itu membentang dari Barat - Timur. Panjangnya kawasan Indonesia, jauh lebih luas dibandingkan dengan Benua Amerika secara melintang. Di kawasan Indonesia ini, terdapat anekaragam suku bangsa, dan juga kondisi geografik.

Secara ekonomi, keadaan alam Indonesia memiliki kekayaan sumberdaya alam (natural resources) yang tinggi. Baik di darat maupun di lautan, terdapat aneka tambang dan sumberdaya hayati yang bisa dimanfaatkan oleh para penghuninya. 
Di lihat dari sudut pandang geologis, Indonesia adalah negara yang berada di atas pertemuan tiga buah lempengan, yaitu lempengan Asia, Pasifik dan Australia. Pertemuan dari tiga lempengan ini, menyebabkan bumi Indonesia labil, potensial terjadi aktivitas geologi, seperti gempa maupun letusan gunung api. Sedangkan, manfaat utama dari adanya aktivitas geologi dibawah bumi Indonesia itu, Indonesia memiliki anekaragam barang tambang di dalamnya. Indonesia adalah negara yang kaya minyak bumi, gas bumi, serta barang tambang lainnya. Semua itu, menunjukkan bahwa keadaan geologi itu, selain memberikan 'rasa nyaman' bagi para penghuninya (karena ada kekayaan alam), juga rasa tidak nyaman karena berada pada situasi rawan bencana.

Berdasarkan sudut sosial budaya, Indonesia adalah negara kepulauan yang dihuni oleh aneka suku bangsa. Motto bhinneka tunggal ika (bahasa sanskerta) yang mengandung arti "berbeda-beda tetap satu juga" menjadi ikatan bathin rakyat Indonesia untuk membangun keutuhan bangsa dan negara di bawah Negara Kesatuan Republik Indonesia.

Di ruang itulah, rakyat Indonesia hadir dan berbudaya. Di tempat seperti itulah, rakyat Indonesia beraktivitas dalam mewujudkan mimpi-mimpinya, baik sebagai manusia maupun sebagai bagian dari warga negara dan warga dunia. Rakyat Indonesia tinggal di satu kawasan dengan garis bujur $95^{\circ} \mathrm{BB}-$ $141^{\circ} \mathrm{BT}$, dan $6^{\circ} \mathrm{LU}-11^{\circ} \mathrm{LS}$. Di sinilah, rakyat Indonesia hidup.

Dalam perspektif yang lebih umum, Bakker (1995:75-76) mengatakan bahwa kita, manusia adalah bagian dari kosmos. Kosmos pada dasarnya bukanlah tumpukan benda yang kacau balau, melainkan merupakan kenyataan yang pluriform. Pada prinsipnya, kosmos merupakan 'rumah tangga' atau 'rumah (oikos, dalam bahasa Yunani), dimana manusia dapat merasa kerasan. Bahkan, lebih lanjutnya di rumah tangga inilah, manusia merasa menjadi utuh, dan bisa melakukan refleksi dan/atau realisasi kemanusiaannya dalam bentuk budaya dan kebudayaan.

Interaksi manusia-alam-kebudayaan, dalam perspektif budaya, merupakan dialektika aktif-dinamis dalam konteks perjuangan manusia (survival) menjadi manusia. (Kusumohamidjojo, 2009:59-72) menerangkan bahwa relasi antara manusia dengan lingkungan itu sendiri, bukan sekedar manusia berusaha untuk bertahan, tetapi beradaptasi dan juga berjuang dalam merealisasikan diri sebagai manusia, kemanusiaan dan kebudayaan. Oleh karena itu, keindonesiaan, budaya Indonesia, atau manusia Indonesia, dapat dipahami sebagai proses real (realisasi) manusia-manusia Indonesia dalam memperjuangkan hidupnya di ruang-geografik-Indonesia itu sendiri. Sumberdaya Indonesia, dinamika geologis, atau dinamika geosfera Indonesia pada umumnya, merupakan bagian penting dan tak terpisahkan dalam membentuk Keindonesiaannya itu sendiri. Realisasi Ahmadun sebagai manusia, warga desa, atau warga Indonesia saat itupun, adalah bagian dari proses real (realisasi) diri dari manusia dan kemanusiaan Ahmadun dalam kehidupannya. 


\section{Pembahasan}

Bagi Budiono Kusumohamidjojo (2009), kebudayaan adalah proses realisasi manusia. Proses ini terjadi, tidak lepas dari ruang tempa tinggalnya. Manusia berbudaya dan kebudayaan manusia, bukanlah proses realisasi yang hampa ruang. Dalam setiap saatnya, proses realisasi manusia senantiasa menyertakan peran ruang dalam mendukung efektifitas realisasi itu sendiri.

Di sepanjang proses realisasi itulah, manusia tinggal, melihat, membaca, mempersepsi dan merekayasa lingkungan (alam yang ada di sekitarnya) sebagai tempat tinggalnya. Dengan potensi-potensi budaya yang dimilikinya, proses pembudayaan itu terjadi, di tempat tinggalnya itu sendiri.

Ada tiga tahapan kesadaran manusia mengenai lingkungannya. Ketiga tahapan itu, memang bukan sesuatu yang terpisah (distance), tetapi lebih merupakan kategori kesadaran diri manusia mengenai lingkungan. Artinya kesadaran itu, hadir dalam diri manusia secara tegas dan jelas, namun bisa berubah dari satu kesadaran ke kesadaran lainnya.

Pertama, ada yang dimaksud dengan pengetahuan geografi (geographic konwledge). Pengetahuan geografi adalah kumpulan konsep, prinsip dan teori geografi. Pembelajaran mengenai pengetahuan geografi mengantarkan pada manusia (peserta didik) untuk sampai pada tahu geografi (I know). Sementara Golledge (2002) mengatakan bahwa pengetahuan geografi merupakan produk dari berfikir geografi.

Peserta didik tahu sebuah gunung tertinggi di dunia, gunung tertinggi di Indonesia, tahu jenis iklim, pembagian flora fauna di Indonesia, dan anekaragam barang tambang yang ada di Indonesia. Bila pengetahuan-pengetahuan itu sudah didapat, maka peserta didik tersebut sudah sampai pada tahapan pengetahuan geografik (Saya Tahu "I know").

Model pembelajaran yang dikembang dalam tahapan ini adalah transfer pengetahuan, atau menyampaikan informasi kepada peserta didik atau masyarakat mengenai berbagai hal yang terkait dengan informasi geografi. Masyarakat atau peserta didik, diberi tahu mengenai keadaan alam yang ada di sekitarnya, dan atau di belahan bumi yang lainnya.

Dalam konteks pendidikan, manusia berposisi atau diposisikan sebagai pengumpul informasi geografi. Berbagai fenomena atau konsep geografi dipelajari, hingga dirinya diserupakan dengan ensiklopedia pengetahuan geografi. "saya tahu" merupakan kunci utama dalam kategori pengetahuan geografi.

Jika kita meminjam pendekatan Bloom, domain dari kategori ini, yakni termasuk domain kognitif. "saya tahu" tentang ini, itu, dan dimana tentang fenomena-fenomena geosfera. Itulah yang disebut dengan pengetahuan geografik. Jenis pengetahuan ini, lebih mengacu pada pengetahuan deklaratif (declarative knowledge).

Kedua, persepsi geografik. Pada kategori ini, peserta didik bukan saja tahu mengenai geografi, tetapi dia mampu memberikan apresiasi atau penilaian 
terhadap lingkungan hidupnya. Dengan penuh pengolahan informasi yang didapat dari lingkungannya, kemudian dia mengkonstruksi pengetahuanpengetahuan geografi itu, menjadi sebuah persepsi geografik (persepsi lingkungan).

Seorang anak muda berliburan ke Pangandaran. Saat liburan ke Pangandaran ini, di mengenakan pakaian tebal dan memakai jaket kulit. Tidak ada yang melarang dia membawa sejumlah pakaian seperti itu. Namun, pakaian yang tebal dan jaket kulit seperti itu, pada dasarnya tidak cocok untuk rekreasi di daerah pantai seperti di Pangandaran. Karena keadaan alam di lokasi ini yaitu panas.

Tindakan yang ditunjukkan oleh anak muda tersebut, menunjukkan ada persepsi lingkungan yang terbentuk dalam dirinya mengenai konsep Pangandaran, yang kemudian mendorong dirinya melakukan sesuatu. Adapun kecocokan/ketidakcocokan atau ketepatan/tidaktepatnya satu pilihan perilaku ruangnya, adalah aspek lain yang perlu dicermati lebih lanjut. Simpul analisis ini adalah adalah persepsi ruang yang dimiliki seseorang akan menuntun adanya sebuah tindakan.

Ketidakcocokan tindakan (respon) terhadap lingkungan, merupakan bentuk dari rendahnya kesadaran geografik pada individu. Sehingga perilaku geografik yang ditunjukkannya kurang relevan dengan situasi dan kondisinya. Wisata ke daerah panas mengenakan pakian jaket kulit, wisata ke daerah dingin mengenakan pakaian berkaos tipis. Tindakan ini adalah bagian dari respon geografi yang kurang tepat, seiring selaras dengan karakter ruang geografiknya.

Ketiga, tindakan geografik. Lanjutan dari persepsi geografik yaitu tindakan geografik. Meminjam perspektif Bloom, yaitu dikategorikan sebagai domain psikomotor. Aspek psikomotor menunjukkan adanya keterampilanketerampilan dasar manusia dalam berinteraksi dengan lingkungan (geographic skill), sedangkan aspek afeksi yaitu pola reaksi individu terhadaplingkungannya. Orang yang sadar, tahu diri, dan bisa berinteraksi dengan lingkungannya akan membentuk kesadaran geografik.

Dimensi psikologis yang tumbuh kembang pada tahapan geografik, yaitu "I care, I act" saya peduli dan saya bertindak. Dua karakter psikologis yang membentuk kesadaran geografik. Sebelumnya, mungkin banyak yang mempersepsikan bahwa tema ini bukan wilayah kajian geografi. Tetapi, bila ditelaah lebih seksama, prinsip "Saya bertindak ( $A c t)$ ", merupakan bentuk nyata dari respon manusia di lingkungannya dan reaksi dirinya terhadap lingkungan geografiknya.

Relasi antara manusia dengan lingkungan, secara teoritik ada tiga kemungkinan, yakni (a) manusia tunduk pada lingkungan (alam), yang kemudian dikenal dengan fisis determinisme, (b) manusia mampu menundukkan lingkungan (alam), yang kemudian disebut posibilisme, dan (c) manusia berinteraksi secara aktif-dinamis dalam mengkonstruksi alam, sehingga bisa 
dijadikan sebagai bagian dari proses realisasi budaya manusia. Dalam filsafat geografi, dikenal dengan aliran probabilisme.

Anekaragam teori ini, mengambarkan 'perbedaan' kemampuan manusia dalam bertindak. Ruang realisasi diri manusia dan kemanusiaan, berbeda secara kualitatif di setiap aliran pemikiran geografiknya itu sendiri. Ruang kemampuan' $I$ Act' pada fisis determinisme, lebih terbatas dibandingkan dengan aliran pemikiran probalibilisme atau posibilisme. Dengan posibilismenya, manusia bersiteguh, mampu merekayasa alam (lingkungan) sebagaimana yang dipersepsikan. Kelompok ini, tidak mengakui bahwa kehidupan manusia ditentukan oleh alam, tetapi alamlah yang ditentukan atau ditundukkan oleh manusia. Fakta selanjutnya, menunjukkan bahwa alam memiliki kemampuan dan manusiapun memiliki keterbatasan, pada sisi lain alam memiliki keterbatasan, dan manusia memiliki kemampuan, sehingga dibutuhkan adanya dialektika dinamik antara kedua komponen ini, dalam merekonstruksi kehidupan dunia ini, sebagai satu relasi yang harmoni di alam semesta ini (alam, atau kosmos).

Dalam ilmu sosial dikenal konsep 'pemberdayaan' (empowerment). Salah satu makna dari pemberdayaan itu, adalah 'memberikan daya-kekuatan' (power) kepada seseorang atau kelompok sehingga mampu memaksimalkan potensi dirinya sebagai manusia. Konsep ini, relevan untuk digunakan dalam menjelaskan tindakan geografi.

Fakta geosfera menunjukkan bahwa ada perbedaan keberdayaan manusia dalam merespon lingkungan. Secara umum, Bakker (1984:58) alam mendorong manusia untuk memperkembangkan daya budinya. Alam adalah tempat tinggal manusia, sekaligus rangsangan (stimulan) manusia dalam merealisasikan diri. Daya rangsang alam (lingkungan) itu direspon manusia secara berbeda-beda. Sehingga pada akhirnya, melahirkan adanya perbedaan fenomena geosfera.

Perbedaan dan persamaan fenomena geosfera, merupakan fakta geografik yang memperkuat pandangan kita bahwa perbedaan dalam pengetahuan geografik dan persepsi geografik, kemudian akan melahirkan adanya perbedaan tindakan geografik. Bahkan, untuk konteks ruang-geografik yang sama pun, menunjukkan adanya perbedaan persepsi geografi dan tindakan geografi yang berbeda.

Aspek pengetahuan dan persepsi, merupakan dua komponen dasar dan penting dalam membangun kesadaran geografi. Wujud nyata dari kesadaran geografi itu, adalah tindakan geografi. Tanpa melihat tepat/tidak tepat, cocok/ tidak cocok, atau mendukung/merusak lingkungan, namun tindakan geografi itu merupakan wujud nyata dari kesadaran geografi seseorang.

Bagi seorang environemtalism, proses penambangan atau pemanfaatan sumberdaya alam saat ini, sejatinya adalah rangsangan nyata untuk mengembangkan paradigma pembangunan berwawasan lingkungan. Ini adalah bentuk dari kesadaran geografik terhadap apa yang terjadi, dan persepsi dirinya terhadap lingkungan yang ada. Sementara bagi seorang teologi, berbagai 
bencana alam yang terjadi saat ini, mengantarkan dirinya untuk sampai pada kesimpulan bahwa perlu adanya reformasi moral dan spiritual manusia, sebagai cara untuk menghadapi berbagai bencana alam ini.

Perbedaan solusi antara yang dikemukakan oleh enviromentalisme dan teologi itu, merupakan sebagian contoh dari kesadaran geografik yang lahir dari adanya pengetahuan dan persepsi dirinya terhadap fenomena geosfera yang ada. Sekali lagi, tanpa melihat aspek tepat/tidak tepat, cocok/tidak cocok, atau mendukung/merusak lingkungan, pengetahuan dan persepsi seseorang tentang fenomena geosfera akan menuntunnya pada lahirnya sebuah tindakan geografik.

Keempat, kebahagiaan geografik. Dini Yulianti, siswa sekolah menengah atas di Kota Bandung study tour ke Pangandaran. Tempat ini merupakan tempat favorit untuk siswa-siswi Bandung. Banyak kelompok yang melakukan study tour ke tempat ini. Namun, kendati acaranya adalah hiburan, dan tempatnya adalah kawasan wisata, namun Dini tampak murung. Kondisi bathinnya tidak tenang, dan tetap merasa gelisah. Rasa gelisah ini, ternyata dirasakan pula oleh sejumlah siswa yang lainnya. Selidik punya selidik, apa yang dia rasakan itu sebagai kulminasi dari persepsi dirinya mengenai lokasi kawasan itu.

Pada tahun 2005 lalu, Pangandaran adalah salah satu daerah di Indonesia yang dilanda aktivitas geologi. Di sinilah terjadi gempa yang kemudian menyebabkan tsunami. Korban tsunami di Pangandaran itu, menelan puluhan bangunan dan merupakan ratusan lahan, serta korban jiwa. Kendati tidak sebesar tsunami Aceh-Nias, namun tsunami di Pangandaran tetap memberikan informasi tertentu kepada siapapun yang hadir di tempat itu. Termasuk Dini dan rekan-rekannya.

Apa yang dirasakan Dini dan rekan-rekannya itu, adalah contoh kecil dari perilaku yang menunjukkan rasa ketidaknyamanan tinggal di satu kawasan. Perilaku yang ditunjukkannya adalah contoh dari rasa tidak bangga, atau tidak bahagia hadir di tempat tersebut. Kendati label politiknya disebut daerah wisata, namun dirinya tidak bisa berlibur atau bersenang-senang di lokasi hiburan ini. Inilah yang kita sebut sebagai hilangnya kebahagiaan geografik.

Dini, dan teman-teman lain yang serupa lainnya, merupakan contoh dari individu yang memiliki sejumlah pengetahuan geografi, serta persepsi geografi. Tetapi, dari persepsi lingkungan itu, yang kemudian melahirkan 'kesadaran lain' tentang ruang tempat liburan (hiburannya) itu, menjadikan suasana batin yang tidak nyaman. Sementara dilain pihak, warga-warga Pangandaran sendiri, tampak asik dan nyaman tinggal di lokasinya ini. Mereka tahu, mengenai kasus yang pernah terjadi beberapa waktu lalu, yang menimpa Pantai Pangandaran dan sebagian warganya. Tetapi, itu semua tidak membuatnya merasa gelisah dan atau meninggalkan lokasi wisata, atau tempat tinggal yang sudah lama dia huni.

Kedua fenomena ini, kita petakan dalam dua kategori, yaitu orang yang merasa tidak nyaman menempati satu ruang, dan kelompok lain adalah orang yang merasa nyaman tinggal dan hidup di tempat tersebut. Dua keadaan itu, 
adalah bagian kecil dari respon manusia terhadap lingkungan, yang dibentuk dari pengetahuan, persepsi serta tindakan tertentu.

Berkembangnya budaya wisata (tourisme), salah satu diantaranya adalah rangka menghilangkan kepenatan dari rutinitas aktivitas kehidupannya. Orang berwisata senantiasa berusaha mencari tempat yang bisa membuat dirinya refresh (segar, bugar) dan mendapatkan kenyamanan. Dengan kegiatan wisata ini, kemudian dia berharap besar, pada hari esoknya akan memiliki kebugaran baru dalam menghadapi dan menjalani rutinisme berikutnya. Dengan kata lain, berwisata itu bukan sekedar mengisi waktu luang, tetapi berusaha memanfaatkan ruang-ruang geografi tertentu untuk mendapatkan kebahagiaan. Tempat yang dipilihnya pun, adalah tempat-tempat yang dipersepsikan mampu merangsang lahirnya persepsi-positif bagi dirinya. Dalam konteks itu, tempat wisata merupakan contoh kecil dari tempat yang mampu melahirkan kebahagiaan geografik (kebahagiaan ruang).

Bumi sebagai tempat tinggal manusia. Sebagai sebuah tempat tinggalnya, manusia berusaha untuk melakukan apresiasi, persepsi, reaksi dan kreasi lingkungan. Semua itu, diorientasikan untuk menciptakan lingkungan yang mendukung pada proses aktif realisasi diri manusia sebagai manusia, dan makhluk lingkungan. Atau dalam istilahlain, yaitu berusaha untuk mewujudkan kenyamanan atau kebahagiaan geografik.

Kebahagiaan geografik (geographic happiness) yang kita maksudkan yaitu hadirnya rasa nyaman, bangga, dan bahagia untuk tinggal di satu tempat. Kebahagiaan geografik, bukan sekedar tahu dan bisa tinggal di satu tempat, tetapi dia bangga dan bahagia tinggal di tempat tersebut. Orang yang sudah memiliki kebahagiaan geografik, tidak sekedar dia tahun kondisi alam di sekitarnya, namun dia mampu merumuskan strategi kebudayaan untuk bisa hidup optimal di daerah yang menjadi tempat tinggalnya.

\section{Diskusi : Konstruksi Pemahaman}

Melalui kerangka pikir itulah, kita dapat melihat perilaku sosial masyarakat Indonesia saat ini. Berbagai hal, baik yang terjadi pada skala daerah maupun skala nasional, dapat kita uraikan dengan sudut pandang geografi, khususnya dengan menggunakan prinsip kebahagiaan geografik.

Kita sempat prihatin, jika ada anak muda Indonesia yang potensial secara intelektual malah kerja di luar negeri (brian fligh). Ketika masih muda, dia menjuarai berbagai olimpiade sains, bahkan diberi beasiswa oleh pemerintah Indonesia. Namun, ketika sudah menjadi ilmuwan malah terbang ke luar negeri dan bekerja di lembaga ilmu negara asing. Kasus yang seperti itu, sudah bukan satu orang, tetapi terjadi pada sejumlah ilmuwan muda Indonesia.

Mereka lakukan itu, bukan tanpa perhitungan. Di negeri Indonesia banyak hal, khususnya sumberdaya alam yang bisa merangsang kreativitasnya, dan ruang pengembangan keilmuannya. Namun, mereka menganggap bahwa di luar negeri ada 'atmosfera' kreativitas dan inovasi yang jauh lebih besar 
dibandingkan bila tinggal di Indonesia. Persepsi yang muncul dalam benak ilmuwan itulah yang kemudian mendorongnya untuk terbang ke luar negeri. Hal itu pun menunjukkan bahwa ilmuwan muda yang terbang ke luar negeri, dan bekerja di luar negeri, adalah contoh nyata kegagalan manusia, masyarakat atau Pemerintah untuk memberikan kenyamanan kepada penghuninya.

Sudah tentu, kita dapat menemukan dua aspek penting yang bisa dikembangkan dalam membahas kebahagiaan geografik ini. Satu sisi, secara struktural menunjukkan bahwa Pemerintah memiliki kewajiban untuk menciptakan lingkungan yang aman, nyaman dan menyenangkan bagi warga negaranya. Pemerintah memiliki peran nyata dalam mendukung mewujudkan kebahagiaan geografik. Pemerintah memiliki banyak sumberdaya yang bisa diberdayakan untuk membangun kebahagiaan geografik.

Krisis politik pada tahun 1997-1998 merupakan contoh lain mengenai kegagalan pemerintah memberikan kenyaman kepada warga negara. Sehingga pada tahun itu, banyak kalangan yang perlu keluar wilayah (hijrah), baik sementara maupun permanen. Mereka pergi bukan tidak tahu mengenai kondisi geografik NKRI, melainkan karena dia merasa tidak nyaman, tidak senang dan tidak bahagia tinggal di Indonesia.

Aspek yang kedua, kebahagiaan geografik dapat dibangun oleh kesadaran individu itu sendiri. Setiap individu memiliki 'energi adaptasi'nya sendiri terhadap lingkungan yang ada. Secara alamiah, manusia memiliki kemampuan untuk beradaptasi dan atau menciptakan rasa bahagianya sendiri. Kasus yang diceritakan di awal, Ahmadun, adalah contoh kecil bagaimana seseorang dengan upayanya sendiri menciptakan lingkungan yang nyaman dan menyenangkan untuk ditinggali.

Pada aspek kedua ini, kebahagiaan geografik adalah usaha sadar individu untuk menciptakan lingkungan sebagai tempat tinggal yang bisa memberdayakan dirinya sebagai warga yang tinggal di tempat tersebut. Dia secara kreatif mengolah dan merekayasa lingkungan, sehingga benar-benar menjadi tempat tinggal yang dia inginkan.

Dia tahu potensi geografik, dan dia memiliki keterampilan untuk berinteraksi dengan lingkungan secara positif. Dengan dua modal kesadaran geografik itulah kemudian dia tumbuh kembang sebagai individu yang sehat di daerah. Ahmadun, bukan saja bisa hidup, tetapi bisa memaksimalkan citacita hidupnya, dengan seluruh keturunannya untuk merealisasikan diri sebagai manusia dan kemanusiaannya di kawasan pesawahan. Hal yang dimiliki Ahmadun itu adalah bagian penting dari upaya individu dalam memberdayakan diri dan lingkungan dalam mewujudkan kualitas hidupnya sendiri.

Karena kemampuannya untuk membangun kebahagiaan geografik di tempat tinggalnya itulah, Ahmadun malah mampu menjadi daya tarik warga desa di daerah lainnya untuk bisa tinggal di sekitar rumah Ahmadun. Dia bukan saja orang yang bersahaja, tetapi mampu bahagia tinggal di kawasan pesawahan. 
Dalam konteks inipun, dapat didiskusikan, bahwa untuk meningkatkan kualitas hidup, diperlukan ada upaya menciptakan tempat kerja, rumah, sekolah, rumah sakit, atau tempat pelayanan publiknya, yang memberikan kebahagiaan geografi. Inilah problema utama kita saat ini. Karena, kasus anak muda modern ini, ternyata lebih mendapatkan kebahagiaan ruang tinggal di pinggir jalan dan lampu stopan, dibandingkan dengan tinggal di rumah atau di sekolah.

\section{Implikasi Pemikiran}

Dari uraian tersebut, dapat disimpulkan bahwa perlu ada satu sistem yang bisa merekayasa lingkungan, sehingga menjadi sebuah tempat tinggal yang mampu mewujudkan kebahagiaan para penghuninya. Ikhtiar ini, perlu dilakukan secara simultan, baik secara struktural maupun kultural (indivisunya sendiri). Karena tanpa ada kesadaran yang sinergis antara Pemerintah dan Individu itu, potensial melahirkan ketegangan geografik (the clash of geographic), yang kemudian menyebabkan individu tidak bahagia tinggal di lokasi tersebut.

Ketegangan geografik adalah suasana bathin individu (warga negara) yang menunjukkan adanya kesenjangan antara kesadaran diri dengan lingkungan. Kesadaran geografik individu (warga negaranya) yang berbeda dengan lingkungannya, menyebabkan ada ketegangan geografik pada individu tersebut. Misalnya, dia merasa tidak betah, tidak mampu berbuat, dan tidak bersikap produktif.

Berdasarkan analisis ini, maka untuk menghindarkan adanya ketegangan geografik, perlu dilakukan beberapa hal penting, baik oleh pemerintah maupun elit sosial lainnya, khususnya kalangan pendidik.

Pertama, dibutuhkan adanya regulasi dalam pengelolaan lingkungan. Untuk mewujudkan kebahagian geografik, pemerintah wajib mengeluarkan kebijakan mengenai pengelolaan lingkungan berbasis masyarakat. Penduduk asli daerah wisata tidak akan memiliki rasa bangga dan bahagia kendati daerahnya ramai dikunjungi banyak wisatawan (asing maupun domestik), ketika lahan di daerahnya sudah banyak dikuasai oleh para pemodal dari luar daerah. Warga asli daerah wisata itu, akhirnya hanya berposisi sebagai kuli di kampungnya sendiri.

Bila pemerintah alpa terhadap kondisi ini, maka kita akan mengalami kesulitan dalam membangun kebanggaan dan kebahagian geografik. Konflik yang berkepanjangan di daerah barang tambang, sudah tentu bukan saja persoalan sosial, melainkan sudah kearah konflik kepentingan ekonomi yang disulut karena tidak adanya kebahagiaan geografik dari warga asli daerah pertambangan tersebut.

Kedua, memaksimalkan kebijakan otonomi pendidikan yang mengangkat muatan lokal. Otonomi pendidikan perlu disahuti sebagai bentuk awal dalam proses memperkenalkan potensi daerah (untuk tahap I know), yang kemudian diharapkan dia peduli dan bangga dengan lingkungannya (I care), dan diharapkan pada satu tahap kehidupannya dia bahagia tinggal di tempatnya sendiri. 
Tingginya migrasi atau urbanisasi, selain menunjukkan adanya kesenjangan agenda pembangunan yang dilakukan pemerintah, atau perbedaan sumberdaya alam, bisa pula disebabkan karena rendahnya kesadaran manusia mengenali potensi daerahnya sendiri. Dalam aspek lain, lemahnya Pemerintah membaca potensi daerah yang bisa dijadikan instrumen pencapaian kesejahteraan rakyat dan bangsanya.

Kita sering mendengar, bahwa Singapura adalah sebuah negara kecil, dengan kekayaan alam yang terbatas. Begitu pula Jepang. Namun, hal yang menarik dari dua negara Asia itu adalah mereka mampu memberdayakan posisi geografik dan sumberdaya manusiannya, sehingga warga negaranya makmur dan sejahtera, bahkan bangga tinggal di negaranya. Hal ini adalah cermin, bahwa kesejahteraan warga negara, bukan disebabkan karena berapa banyak kekayaan alam yang miliki, melainkan berapa kuat kita mampu mengembangkan potensi yang ada. Itulah kunci dari upaya membangun kebahagiaan geografik.

Ketiga, perlu ada upaya untuk memindahkan mindset masyarakat dari paradigma $i k n o w$, menuju Icaresampai pada Ican. Titik kemampuan(Ican)adalah relevansi tindakan seseorang dalam memaksimalkan potensi baik diri maupun lingkungan untuk mewujudkan kebutuhan hidupnya. Ketidak berdayaan manusia untuk mengembangkan kemampuan itu, selain akan menyebabkan adanya ketegangan geografik, akan menjadikan termarginalkannya manusia sehingga dia terpuruk di daerah, dan/atau pindah ke luar kota.

Tidak sedikit yang tahu (I know) mengenai potensi geografi Indonesia. Baik sumberdaya alam yang ada di darat maupun laut. Banyak yang sudah mengetahui hal ini. Namun dari pengetahuan yang dimilikinya itu, hanya sedikit orang yang peduli untuk memberdayakannya. Di lain pihak, yang peduli itu pun, hanya sedikit orang yang bahagia dalam memanfaatkannya.

Para penebang liar, adalah contoh lain mengenai orang yang tahu dan peduli dengan sumberdaya alam, namun tidak bahagia dengan lingkungannya. Oknum itu, hanya memanfaatkan sumberdaya alam, kemudian dia meninggalkan ruang geografik kekayaan alam. Dia tidak bangga dengan lingkungannya, dan tidak bertanggungjawab. Pada konteks itu, dia gagal menciptakan rasa bangga dan bahagia di lingkungan. Sikap merusak yang ditunjukkannya adalah kesadaran memanfaatkan yang tidak dikawal oleh kesadaran untuk bisa bahagia di tempat.

Orang yang memiliki kebahagiaan geografi adalah orang yang sadar untuk memanfaatkan sumberdaya alam dan bertanggungjawab terhadap kelanjutan kelestarian lingkungannya. Kepekaan terhadap nasib alam, dikembangkan dengan kepeduliannya untuk menjaga kelestarian lingkungan. Itulah dimensi penting dalam aspek kebahagiaan geografik.

Dengan demikian, para pengusaha atau siapapun yang hanya bisa memanfaatkan kekayaan alam tanpa menunjukkan sikapnya untuk peduli pada kelestarian alam merupakan kontributor utama dalam menciptakan 
kitidakbahagiaan geografik. Karena apa yang dilakukannya itu, selain menunjukkan dirinya tidak bangga dengan lingkungan, juga tidak peduli dengan masa depan lingkungannya.

\section{Tentang Nasionalisme}

Pada dasarnya, kita tidak akan mengalami banyak kesulitan dalam membangun nasionalisme warga negara. Tidak perlu berkeluh kesah dan atau merasa khawatir dengan nasionalisme rakyat Indonesia. Dimanapun dia tinggal, baik di desa maupun di kota, di dalam maupun di luar negeri. Sepanjang dirinya mampu menunjukkan rasa bangga, dan bahagia berbangsa Indonesia, nasionalisme itu akan muncul.

Kealpaan kita selama ini, pendidikan nasionalisme lebih banyak diisi oleh pendidikan aspek politik. Dijejali anak muda dengan ideologi politik, walaupun sayangnya yang diajarkan pun bukan ideologi kebangsaan melainkan ideologi penguasa dan kekuasaan. Sehingga, pendidikan politik yang dilakukan Orde Baru selama 32 tahun, tidak melahirkan generasi muda yang cinta bangsa dan tanah air (patriotisme), melainkan menjadi pengeruk kekayaan negara untuk kepentingan pribadi dan atau kelompok.

Nasionalisme bisa dibangun. Tetapi, perlu melibatkan pendidikan geografik. Nasionalisme bukanlah masalah politik semata. Nasionalisme adalah masalah usaha sistematis dalam membangun kebanggaan untuk berbangsa, dan bertanah air Indonesia. Oleh karena itu, pendidikan pengetahuan geografik dan kesadaran geografik menjadi sangat penting. Karena dengan pendidikan geografik itulah, seseorang akan mulai tahu, sadar dan peduli terhadap lingkungannya.

Para pendiri bangsa, seperti halnya Soekarno, memaknai Nasionalisme itu sebagai bentuk rasa cinta terhadap tanah air (nasionalisme atau patriotisme). Adalah masuk akal, rasa cinta terhadap tanah air itu bisa terwujud, bila dirinya memiliki pengetahuan geografik, persepsi geografi, dan mampu menunjukkan perilaku geografi yang menjadi jalan bagi dirinya dalam meraih sebuah kebahagiaan ber-Indonesia. Kegigihan dalam memperjuangan kemerdekaan Indonesia pun, pada dasarnya karena dia berharap dia bisa hidup dalam ruang-geografik Indonesia, yang merdeka, berdaulat, adil dan makmur. Itu semua, menunjukkan bahwa perjuangan kemerdekaan Indonesia, adalah usaha pemerdekaan kehidupan rakyat Indonesia, sehingga menjadi kebahagian hidup di Indonesia.

Sekali lagi, perlu ditegaskan, di zaman Orde Baru memang pernah ada pendidikan Wawasan Nusantara atau Penataran P4 (Pedoman Penghayatan dan Pengamalan Pancasila). Karena dominasi ideologi kekuasaan yang berlaku, maka program pemerintah tersebut, tidak efektif membangun nasionalisme kaum muda. Kaummuda waktu itu, tidak tulus dan tidakmampu menghadirkan kebahagiaan geografiknya untuk berbangsa dan bertanah air Indonesia. Namun demikian, pengalaman itu bukan berarti, pendidikan nasionalisme menjadi 
tidak perlu. Pendidikan nasionalisme itu adalah bagian penting dalam proses pendidikan karakter. Dengan kata lain, dapat dikemukakan bahwa pendidikan geografi pada dasarnya memiliki potensi strategis untuk mendukung usaha pendidikan karakter bangsa (national character building), sehingga melahirkan generasi yang bangga dengan Indonesia, dan bahagia hidup di Indonesia.

\section{SIMPULAN DAN REKOMENDASI}

Kita sering kali berbicara mengenai kebahagiaan. Kebahagiaan manusia itu, tidak saja disebabkan oleh masalah kepemilikan (the have) yang berdimensi materi, melainkan erat kaitannya dengan aspek immaterial, lebih tepatnya lagi yaitu aspek spiritual. Salah satu aspek immaterial itu yaitu terkait dengan aspek the have yang sifat modal intelektual (intelectual capital). Salah satu modal intelektual yang perlu dikembangkan itu, yaitu kemampuan untuk merekayasa secara kreatif dan produktif mengenai sumberdaya geografik (lingkungan). Kegagalan seseorang dalam merekayasa lingkungan, potensial melahirkan kesenjangan geografik.

Kemampuan merekayasalingkunganitupun, perlu ditingkatkanlagi, pada tahap pemaknaan terhadap lingkungan (meaningfull). Kebermaknaan hidup dalam ruang geografi. Karena hanya dengan kemampuan mengembangkan makna dan kebermaknaan lingkungan bagi kehidupannya itulah, seseorang akan mampu meraih kebahagiaan geografi. Di sinilah, aspek spiritualitas dalam pengembangan kebahagiaan geografik menjadi penting.

Perbedaan jarak ekonomi antara satu orang dengan orang lain disebut kesenjangan ekonomi. Sedangkan yang dimaksud dengan kesenjangan geografi yaitu ketidaksesuaian antara potensi lingkungan dengan kesejahteraan individu. Manusia yang secara filosofis memiliki potensi paling mulia untuk mendapatkan kebahagiaan hidup, dan memiliki ruang paling terbuka untuk menggapai kebahagiaan hidup, sejatinya harus mampu mendapatkan kebahagiaan geografi. Andaipun hal itu sulit diwujudkan, maka ada dua kemungkinan yang bisa terjadi, yaitu lingkungan yang sudah rusak, dan tidak bisa mendukung lagi kehidupan manusia, atau manusianya yang tidak berdaya di tengah-tengah lingkungan. Tetapi, kesimpulan dari dua aspek itu, sesungguhnya dapat dikatakan, itulah dua fakta geografik yang menunjukkan adanya kesenjangan geografik.

Dalam wacana ini, ada dua istilah yang serupa dengan konsep lain yang serupa dengan fakta ini, yaitu ketegangan geografik. Saya mengartikan, kesenjangan geografik itu dalam pengertian statik. Misalnya ada perbedaan antara potensi dengan faktual. Indonesia adalah negara yang dipersepsikan sebagai negara yang kaya raya dengan sumberdaya alamnya, tetapi rakyatnya kurang sejahtera. Ini adalagh fakta yang bersifat statik. Itulah yang disebut dengan kesenjangan geografi. Sedangkan kesenjangan geografik yang melahirkan reaksi dari manusia, atau reaksi dari alam (seperti bencana) 
merupakan bentuk dari ketegangan geografik. Aspek ketegangan geografik ini, saya maksudkan untuk makna dinamis.

Akibatdarikesenjangan geografikitu, selain melahirkan ketidakbahagiaan geografik, juga akan melahirkan ketegangan geografik. Salah satu reaksi yang muncul dalam diri manusia itu, adalah mendorong dirinya keluar dari ruang geografiknya. Urbanisasi, migrasi atau pindah kewarganegaraan, merupakan contoh-contoh lain adanya ketidakbahagiaan geografik pada satu tempat, dan memimpikan mendapatkan kebahagiaan geografik di tempat lain.

Berdasarkan pertimbangan tersebut, dan juga merujuk pada analisis kritis kita terhadap tujuan pendidikan geografi, maka melalui pendidikan, pembinaan dan penyadaran geografik itulah diharapkan dapat melahirkan kebahagiaan geografik yang mendorong terbangunnya rasa tanggungjawab manusia atau warga negara terhadap lingkungan yang lebih baik. Manusia yang cinta pada kebutuhan hidup maasa depannya adalah manusia yang mencintai dirinya dan lingkungannya. Kebahagiaan manusia di masa depan, hanya dapat diwujudkan dengan optimal dalam bentuk bahagia hidup dalam ruang-hidupnya itu sendiri. Bahagia itu bukan sekedar masalah perasaan, tetapi bahagia dalam hidup itu adalah bahagia menempati sebuah ruang. Dengan kesadaran itulah, Ahmadun-Ahmadun yang lain bisa hadir di bumi Indonesia. Dia tinggal di Indonesia, dia bangga dengan Indonesia dan dia sejahtera di Indonesia. Dia pun bahagia dengan Indonesia.

\section{DAFTAR PUSTAKA}

Arif, Irwandy. (2011). Good Minning Practice. Makalah pada Seminar Pertambangan Dan Pendidikan Dini. Bandung ; UNISBA-UPI.

Bakker, Anton. (1995). Kosmologi dan Ekologi. Jogjakarta : Kanisius.

Bakker, JWM. (1984). Filsafat Kebudayaan : Sebuah Pengantar. Jogjakarta : Kanisius.

Daldjoeni, N. (1996). Filsafat Geografi. Bandung : Alumni.

Gibson, Chris. (2009) Geographies of tourism: critical research on capitalism and local livelihood. Prog Hum Geogr 2009; 33; 527 originally published online Mar 9, 2009. [Online]. Tersedia: http://phg.sagepub.com by momon sudarma on October 3, 2009.

Giddens, Anthony. (2003). The Constitution of Society : Teori Strukturasi Untuk Analisis Sosial. Penerjemah Adi Loka Sujono. Yogyakarta : Pedati.

Golledge, Reginald G. (2002). The Nature of Geographic Knowledge. Annals of the Association of American Geographers, 92(1), 2002, pp. 1-14. Published by Blackwell Publishing, 350 Main Street, Malden, MA 02148, and 108 Cowley Road, Oxford, OX4 1JF, UK.

Herry-Priyono, B. (2003). Anthony Giddens : Suatu Pengantar. Jakarta : Kepustkaan Populer Gramedia.

Jackson, Peter. (2006). Thinking Geographically. Geography Vol. 91 (3). Halaman 199-204. 